\title{
Sosialisasi dalam Rangka Pencegahan, Peningkatan Kesadaran dan Pemahaman Masyarakat tentang COVID-19 di Desa Panaguan Kec. Larangan
}

\author{
${ }^{1}$ Shohibul Fadil, ${ }^{2}$ Jamiludin Usman \\ Institut Agama Islam Negeri Madura, Jl. Raya Panglegur Km. 4 Pamekasan 69371 \\ ${ }^{1}$ fadil@gmail.com, ${ }^{2}$ jamiludin.usman@iainmadura.ac.id
}

\begin{abstract}
The occurrence of the Coronavirus (COVID-19) emergency affected public health. As for community service is to provide understanding to the community about COVID-19, and how to prevent it by washing hands and wearing masks in Panaguan village. These movements have great benefits in raising awareness for the community in the prevention of dangerous organisms, both viruses, bacteria, and fungi that can cause disease transmission.
\end{abstract}

Keywords: Corona Virus; Socialization

\begin{abstract}
Abstrak
Terjadinya bencana virus Corona (COVID-19) memberikan pengaruh terhadap kesehatan masyarakat. Adapun tujuan dari pengabdian masyarakat ini adalah untuk memberikan pemahaman kepada masyarakat terkait COVID-19, serta cara mencegah dengan cara mencuci tangan dan menggunakan masker di Desa Panaguan. Gerakan ini memiliki manfaat besar dalam menimbulkan kesadaran bagi masyarakat dalam pencegahan dari organisme berbahaya, baik virus, bakteri, maupun jamur yang dapat menyebabkan penularan penyakit.
\end{abstract}

Kata Kunci: Virus Korona; Sosialisasi

\section{Pendahuluan}

Disadari atau tidak bahwa mahasiswa merupakan ikon atau simbol dari potret kehidupan masyarakat dalam skala yang lebih kecil. Sejarah juga mengatakan bahwa perubahan Negara kita tercinta dari sistem Negara yang otoriter menuju sistem Negara yang demokratis adalah berkat perjuangan dari mahasiswa yang ada di nusantara. Hal ini menjadi dasar bahwa mahasiswa mempunyai peranan yang sangat penting dalam mengawal perubahan baik dari tataran masyarakat yang kecil sampai masyarakat yang lebih luas.

Sering kita dengar tentang simbol yang sering diberikan kepada Mahasiswa yaitu bahwa mahasiswa adalah sebagai "Agent of Change" dan "Agent of Social Control". Dan perlu diketahui dengan melekatnya simbol dan jargon-jargon tersebut dipundak seorang mahasiswa, hal ini menunjukkan bahwa terdapat tanggung jawab besar dipundak mahasiwa terhadap keberlangsungan stabilitas kehidupan sosial kemasyarakatan.

Dari hal itulah mahasiswa tidak hanya memiliki kewajiban belajar tentang beberapa teori-teori ilmu pengetahuan, tetapi mereka juga memiliki 
tanggung jawab terhadap perubahan sosial yang ada. Mereka juga dituntut untuk mengabdi dan mengaplikasikan apa yang telah mereka dapat dibangku kuliah secara praktis dan bersentuhan langsung dengan problematika masyarakat, karena mahasiswa adalah juga merupakan bagian kecil dari masyarakat.

Berdasarkan "Tri Dharma Perguruan Tinggi" yang berisikan pendidikan dan pengajaran, penelitian, dan pengabdian. Maka terlihat jelas tugas dan peran mahasiswa yaitu meliputi tiga aspek tersebut. Aspek pertama persoalan pendidikan dan pengajaran, Mahasiswa telah menunaikannya dalam bangku kuliah di kampus, dengan mempelajari beberapa teori ilmu pengetahuan. Aspek yang kedua Penelitian mereka juga telah mendapatkannya dibangku kuliah yang berupa teknik-teknik serta teori-teori dalam penelitian. Sedangkan aspek yang ketiga yaitu Pengabdian, seorang mahasiswa dituntut terjun langsung untuk melakukan pengawalan terhadap perubahan sosial kemasyarakatan, baik dalam hal pengembangan ekonomi masyarakat, pendidikan, agama, kesehatan ataupun sosial politik masyarakat.

Sebagai media awal untuk memenuhi tanggung jawab mahasiswa dan menunaikan ketiga rukun tri dharma perguruan tinggi tersebut, Institut Agama Islam Negeri Madura mengadakan Kuliah Pengabdian Kepada Masyarakat (KPM) sebagai bentuk perwujudan ketiga Tri Dharma Perguruan Tinggi tersebut. Dalam KPM mahasiswa tidak hanya mengabdi kepada masyarakat, sekaligus menjaga kesehatan masyarakat sekitar di tengah terjadinya COVID ini. Mahasiswa yang melaksanakan KPM di daerah masing-masing dengan cara memperhatikan protokol kesehatan yang telah ditetapkan oleh pemerintah.

Hal ini sudah terjadi beberapa bulan terakhir sebelum kuliah pengabdian masyarakat ini dimulai. Di semua Negara sudah terjadi terlebih dahulu yang namanya wabah virus Coronatak terlepas juga terjadi pada masyarakat sekitar dengan adanya virus Corona yang menyebabkan resah nya masyarakat sekitar. Untuk kesadaran masyarakat juga masih bermacammacam tanggapan yang di utarakan oleh beberapa orang mulai dari mengikuti anjuran pemerintah tentang pentingnya mematuhi protokol kesehatan dan bahkan ada juga yang acuh tak acuh terhadap anjuran pemerintah tersebut dengan beragam alasan yang mereka utarakan.

Dalam sejarah peradaban manusia, pengaruh penyakit terhadap kematian kiranya menjadi signifikan tatkala manusia mulai memasuki peradaban agraris. Pada masa berburu dan meramu, kematian lebih banyak disebabkan oleh kurangnnya nutrisi, intaficide atau pembunuhan bayi, dan geronticide atau pembunuhan orang usia tua. Namun, setelah memasuki era revolusi agraris, faktor yang menyebabkan kematian berubah. Meskipun manusia sudah memiliki nutrisi yang lebih baik, tetapi kontak satu sama lain yang semakin dekat, baik sesama manusia atau manusia dengan hewan, telah menjadikan penyakit semakin mudah menular dan menjadi ancaman baru bagi kehidupan. Kontak terhadap hewan ini pula yang belakangan diketahui sebagai penyebab virus yang sedang menjangkit dunia akhir akhir 
ini, yaitu Coronavirus. Menyebutkan bahwa pola makan manusia yang semakin gemar mengonsumsi protein hewani menjadi peluang bagi virus Corona menyebar dari hewan ke manusia (European Centre for Disease Prevention and Control, 2020).

Permasalahan yang penulis angkat pada artikel ini adalah sosialisasi dalam rangka pencegahan, peningkatan kesadaran dan pemahaman masyarakat tentang COVID-19. Oleh karena itu, peserta KPM mengajak masyarakat agar menjaga kesehatan untuk mencegah bahaya COVID melanda dan menanamkan kesadaran kepada masyarakat tengtang bahaya COVID-19. Dengan tujuan diharapkan mampu menumbuhkan kesadaran masyarakat sekitar daerah KPM tentang bahayanya wabah virus Corona tersebut.

KPM adalah kuliah pengabdian masyarakat. Kuliah pengabdian masyarakat merupakan suatu wujud kristalisasi dan integralisasi dari ilmu yang tertuang secara teoritis dibangku kuliah untuk diterpakn secara nyata dalam kehidupan sehari-hari di masyarakat, sehingga ilmu yang diperoleh dapat diaplikasikan dan dikembangkan dalam kehidupan masyarakat luas (Nur'aini \& Wijaya, 2015: 92). Kuliah Pengabdian Masyarakat adalah suatu kegiatan yang bertujuan membantu masyarakat tertentu dalam beberapa aktivitas tanpa mengharapkan imbalan dalam bentuk apapun. Secara umum program ini dirancang oleh berbagai universitas atau institut yang ada di Indonesia untuk memberikan kontribusi nyata bagi bangsa Indonesia, khususnya dalam mengembangkan kesejahteraan dan kemajuan bangsa Indonesia (Wikipedia Bahasa Indonesia, 2020).

Kuliah Pengabddian Masyarakat merupakan bentuk kegiatan pengabdian kepada masyarakat yang bersifat khusus, karena dalam KPM darma pendidikan dan pengajaran, penelitian serta pengabdian kepada masyarakat dipadukan kedalamnya dan melibatkan sejumlah mahasiswa dan sejumlah staf pengajar ditambah unsur masyarakat. Pengertian pengabdian kepada masyarakat ialah pengalaman ilmu pengetahuan, teknologi dan seni yang dilakukan oleh Perguruan Tinggi secara ilmiah dan melembaga langsung kepada masyarakat untuk mensukseskan pembangunan dan pengembangan manusia pembangunan menuju tercapainya manusisa yang maju, adil dan sejahtera berdasarkan Pancasila, serta meningkatkan pelaksanaan misi dan fungsi Perguruan Tinggi.

KPM juga merupakan wahana penerapan serta pengembangan ilmu teknologi, dilaksanakan diluar kampus dalam waktu, mekanisme kerja, dan persyaratan tertentu. Dapat disimpulkan bahwa KPM adalah kegiatan intrakulikuler yang memadukan pelaksanaan Tri Darma yang dilaksanakan oleh mahasiswa dengan bimbingan dosen dan masyarakat.

Kuliah pengabdian kepada masyarakat (KPM) merupakan kegiatan akademik terstruktur dan mandiri yang menjadi bagian tak terpisahkan dari pelaksanaan kurikulum pendidikan tinggi, khususnya pada IAIN Madura, yang harus diselenggarakan secara terencana, terlembaga, berkala, dan berkesinambungan (Hasan \& dkk, 2018: ii). 
Kegiatan pengabdian kepada masyarakat merupakan salah satu komponen kegiatan akademik dan hal itu merupakan bagian dari Tri Dharma Perguruan Tinggi, setelah pendidikan dan penelitian. Semua ini harus bisa dilakukan oleh segenap mahasiswa agar supaya bisa memberikan sumbangsih ilmu pengatahuannya kepada masyarakat (Hasan \& dkk, 2018: 4).

Dengan melihat judul yang saya ambil yaitu tentang sosialisasi dalam rangka pencegahan, peningkatan kesadaran dan pemahaman masyarakat tentang COVID-19 maka saya akan menjelaskan secara detail tentang judul yang saya pilih untuk memudahkan pembaca memahami isi dari tema tersebut.

Coronavirus merupakan virus RNA strain tunggal positif, berkapsul dan tidak bersegmen. Coronavirus tergolong Ordo Nidovirales, keluarga Coronaviridae. Coronaviridae dibagi dua subkeluarga dibedakan berdasarkan serotipe dan karakteristik genom. Terdapat empat genus yaitu alpha Coronavirus, betaCoronavirus, deltaCoronavirus dan gamma Coronavirus (Burhan, 2020: 3). Virus Corona berbentuk bulat dengan diameter sekitar $125 \mathrm{~nm}$ seperti yang digambarkan dalam penelitian menggunakan cryo-electron microscopy. Partikel virus Corona mengandung empat protein struktural utama, yaitu protein $S$ (spike protein) yang berbentuk seperti paku, protein $\mathrm{M}$ (membrane protein), protein $\mathrm{E}$ (envelope protein), dan protein $N$ (nucleocapside protein). Protein $S(\sim 150 \mathrm{kDa})$, protein $\mathrm{M}(\sim 25-30 \mathrm{kDa})$, protein $\mathrm{E}(\sim 8-12 \mathrm{kDa})$, sedangkan protein $\mathrm{N}$ terdapat di dalam nukleokapsid (Parwanto, 2020).

Virus Corona merupakan keluarga besar virus yang menyebabkan infeksii saluran pernafasan atas ringan hingga sedang, seperti penyakit flu. Banyak orang yang terinfeksi virus ini setidaknya satu kali dalam hidupnya. Pada zaman dahulu virus ini sudah mewabah yang menyebabkan banyak orang yang meninggal di sebabkan virus tersebut. Virus tersebut yang terjadi pada zaman dahulu itu dinamakan dengan penyakit to'un yang menyebabkan orang meninggal hingga 70.000 (tujuh puluh ribu) orang.

Didalam gejala virus Corona ini secara umum dapat ditandakan dengan beberapa gejala yaitu:

a. Gejala demam yang mencapai suhu tubuh di atas 38 derajat celcius. Tapi tidak segala suhu tubuh yang diatas 38 derajat celcius langsung divonis mengalami penyakit COVID.

b. Gejala batuk-batuk, gejala ini sering terjadi pada manusia tapi tidak semuanya dikarenakan virus Corona.

c. Gejala sesak nafas, hal ini sudah sering terjadi pada manusia dan tidak semuanya karena virus Corona. Ada yang terjadi dikarenakan pecandu rokok, mempunyai penyakit asma' dan lain sebagainya.

d. Gejala pusing. Gejala ini sering juga terjadi pada semua manusia yang tak terlepas dari semua itu. Dan bukan semuanya dikarenakan karena virus Corona ada juga dikarenakan kekurangan darah dan juga keseringan kurang tidur atau begadang. Tapi disamping itu disebakan karena virus Corona. 
Virus Corona merupakan penyakit baru yang terjadi pada tahun kemarin ini sehingga dapat meresahkan lapisan semua masyarakat yang tak terkecuali. Sehingga dapat menyebarkan virus yang sangat bahaya ini. Terdapat beberapa bagian virus Corona ini menyebar dengan cepat, diantaranya:

a. Menyentuh bagian yang biasa disentuh oleh orang lain tanpa langsung mencuci tangan terlebih dahulu.

b. Adanya kontak jarak dekat dengan sesama manusia yang dapat menyebarkan virus Corona menyebar.

c. Berbicara terlalu keras sehingga dapat mengeluarkan ludah yang mebawa virus Corona.

d. Adanya batuk dan bersin-bersin sehingga dapat menyebabkan virus.

e. Tidak menjaga kesehatan lingkungan sekitar atau hidup dalam suasana kotor.

f. Tidak menjaga imunitas tubuh sehingga cepat terkena virus Corona.

Maka dari itu, sebagai insan yang lemah harus menjaga kesehatan tubuh termasuk imunitas tubuh supaya dapat menjaga tubuh tersebut terhindar dari gejala virus Corona dan juga dapat mencegahnya dan tidak menularkannya pada sesama manusia.

Sampai saat ini gejala virus Corona ini masih belum ditemukan obat atau vaksin yang dapat mengobati gejala virus Corona tersebut. Oleh karena itu, cara mencegah virus Corona itu sudah dianjurkan dengan cara menghindari factor-faktor yang bisa menyebabkan virus Corona, diantaranya:

a. Menghunakan masker apabila sedang beraktivitas ditempat umum, seperti sedang bekerja, masuk rumah sakit, undangan, perjalanan dan lain-lain.

b. Menerapkan physical distancing, atau menjaga jarak antar sesama manusia supaya dapat mencegah menularnhya virus Corona.

c. Mencucui tangan secara terus menerus setelah melakukan kegiatan yang berlangsung.

d. Rutin mencuci tangan dengan air dan sabun atau hand sanitizer yang mengandung alkohol, terutama setelah beraktivitas di luar rumah atau di tempat umum.

e. Jangan menyentuh mata, mulut, dan hidung sebelum mencuci tangan apabila sudah melakukan aktivitas lapangan.

f. Tingkatkan daya tahan tubuh dengan pola hidup sehat. Dengan cara sering berolahraga dan mengeluarkan keringat.

g. Hindari kontak dengan penderita COVID, orang yang dicuragai positif terinfeksi virus Corona, atau orang yang sedang sakit demam, batuk atau pilek.

Sosialisasi sebagai proses belajar seorang individu merupakan salah satu faktor yang mempengaruhi bagaimana keberlangsungan proses kehidupan masyarakat, sekolah maupun media massa. Unsur unsur pengertian sosialisasi adalah sosilisasi merupakan cara belajar atau suatu 
proses akomodasi dan yang di pelajari adalah nilai nilai, norma norma, ide ide atau gagasan, pola pola tingkah laku dan istiadat serta keseluruhannya itu di wujudkan dalam kepribadiannya (Hanum, 2006: 25). Keseluruhannya itu merupakan segala aspek dari proses kehidupan manusia yang berhubungan erat dengan sosialisasi menyangkut keberhasilan ataupun kegagalan sosialisasi.

Sosialisasi juga sebagai proses belajar individu dalam kehidupan bermasyarakat, kehidupan yang berpedoman pada norma norma. Norma merupan kaidah,pokok, kadar atau patokan yang di terima secara utuh oleh masyarakat guna mengatur kehidupan kehidupan dan tingkah laku sehari hari, agar hidup ini terasa aman dan menyenangkan (Kartono, 2007: 11).

\section{Pelaksanaan Kegiatan}

Dalam pelaksanaan kuliah pengabdian masyarakat ini dilakukan secara bersama-sama dengan berkolaborasi dengan karang taruna desa panagguan kecamatan larangan. Tempat yang di jadikan sasaran kegiatan pengabdian masyarakat adalah balai desa yang ada Desa Panaguan, Kecamatan Larangan, Kabupaten Pamekasan. Waktu yang sudah menjadi sosialisasi adalah pada tanggal 03 Juni 2020 pada jam 08.00 wib. Pada waktu itu di mana masyarakat masih belum banyak yang mengenal mengenai wabah virus Corona ini ada dan berlangsung dan dapat bisa meresahkan masyarakat.

Adapun tahap pelaksanaan kegiatan ini meliputi;

Sosialisasi Pertama, yang membahas tentang pemahaman COVID:

a. Dalam pembahasan tentang COVID-19 adalah penyakit akibat suatu Coronavirus baru yang sebelumnya tidak terindentifikasi pada manusia. Corona virus adalah suatu kelompok virus yang ditemukan pada hewan dan manusia.

b. Apa saja gejala gejala COVID-19? COVID-19 menyebabkan gejala ringan seperti pilek, sakit tengorokan, batuk, dan demam. Bagi beberapa orang, gejalanya bisa lebih parah, dan menimbulkan radang paru paru atau sulit bernafas. sejumlah kecil kasus ini menyebabkan kematian.

c. bagaimana cara penyebaran COVID-19? COVID-19 diketahui paling mudah menyebar melalui kontak erat dengan orang yang terinfeksi Covid-19, batuk atau orang yang terinfeksi mengeluarkan percikan dan, jika terlalu dekat, virus ini dapat masuk melalui nafas.

d. Siapa yang paling berisiko? yang paling beresiko adalah orang berusia lanjut dan orang yang memiliki kondisi medis seperti diabetes dan penyakit jantung diketahui lebih beresiko terkena virus ini.

e. Apa pengobatan untuk COVID-19? saat ini masih belum ada pengobatan atau vaksin untuk COVID-19. Namun, sebagian besar gejala dapat di tangani.

Sosialisasi kedua, membahas tentang hal apa saja yang harus dilakukan diantaranya: 
a. Sering seringlah mencuci tangan.

Cuci tangan dengan air bersih mengalir dan sabun atau, jika tidak tampak kotor, gunakan cairan antiseptik berbahan dasar alkohol. maka, virus di tangan akan mati.

b. Tutup mulut dan hidung dengan siku yang dilipat atau tisu saat batuk dan bersin.

Segera buang tisu bekas dan cuci tangan dengan air bersih mengalir dan sabun atau gunakan cairan antiseptik berbahan dasar alkohol. Dengan demikian anda melindungi orang lain dari virus yang keluar melalui batuk dan bersin.

c. Jika memungkinkan jaga jarak 1 meter dengan orang yang batuk batuk, bersin bersin, atau demam.

COVID-19 diketahui paling mudah menyebar melalui kontak jarak dengan orang yang sedang terinfeksi COVID-19

d. Jangan sentuh mata, hidung dan mulut.

Tangan menyentuh berbagai permukaan benda yang mungkin terkontaminasi virus ini. Jika menyentuh mata, hidung atau mulut dengan tangan kotor, mungkin memindahkan virus ini dari permukaan ke dalam tubuh.

e. Jika demam, batuk dan sulit bernafas, cari petolongan medis. telepon fasilitas kesehatan dan sampaikan dulu bahwa anda akan datang.selalu ikut panduan tenaga kesehatan atau petunjuk kesehatan nasional.

Sosialisasi ketiga, membahas tentang cara cuci tangan yang benar untuk cegah virus Corona COVID-19, cuci tangan merupakan langkah mudah dan aman untuk melindungi diri dari virus COVID-19, tetapi tidak banyak yang tahu bagaimana cara mencuci tangan yang benar.

Berikut tata cara mencuci tangan dengan benar, diantaranya:

a. Membasuh tangan dengan air yang bersih.

b. Memberikan sabun atau diterjen yang dapat membunuh kuman dengan melumuri pada seluruh permukaan tangan.

c. Menggosok telapak tangan supaya kuman-kuman yang menempel mati seluruhnya.

d. Menggosok punggung tangan dan jari-jari tangan serta kuku bagian dalam hingga bersih.

e. Menggosok jari-jari, telapak tangan, punggung tangan, hingga pada lengan agar kuman mati secara menyeluruh.

f. Menggosok seluruh permukaan tangan yang bersabun hingga bersih dengan air yang mengalir.

g. Mengeringkan tangan dan di lap secara bersih dengan kain atau semacamnya dengan satu kali pakai.

Selain itu, ada juga solusi yang lebih extra dan lebih simple yaitu dengan cara cuci tangan memakai cairan hand sanitizer. Yang mana hand sanitizer ini mengandung alcohol yang dapat dan mampu membunuh kuman. Meskipun tidak bisa membunuh kuman secara kesuluran yang pasti hand sanitizer ini mampu membunuh secara efektif. 
Ini dapat dilakukan dengan cara memberikan cairan hand sanitizer pada tangan lalu di gosokkan kepada seluruh permukaan tangan dan juga pada sela-sela jari tangan dan juga pada sela-sela kuku-kuku tempat kuman menempel.

Sosialisasi keempat, membahas tentang perilaku hidup bersih pada lingkungan sekitar tak terkecuali dirumah yang mana ini penting. Pola hidup bersih dan sehat adalah kebiasaan yang penting untuk diterapkan. Perilaku pola hidup bersih dan sehat termasuk dalam menjaga kebersihan lingkungan.

Ada beberapa kegiatan yang saya laksanakan pada gerakan lingkungan sehat dan bersih untuk meningkatkan kebersihan antara lain:

a. Membersihkan lingkungan tempat sekitar

Kegiatan ini di lakukan bersama Desa dengan kegiatan membersihkan sekitar lingkungan rumah masyarakat sekitar. Pertama yang di lakukan yaitu dengan cara mengajak masyarakat yang memiliki rumah disekitar lingkungan yang akan jadikan objek untuk kegiatan bersih-bersih. Kedua yaitu memilih lingkungan yang memang benar-benar terlihat tidak bersih dan perlu dibenahin keadaan lingkungannya. Ketiga, melakukan kegiatan gerakan lingkungan bersih bersama kelompok KPM dan karang taruna Desa sampai selesai dan lingkungannya sampai terlihat sudah sehat dan bersih.

b. Membersihkan selokan

Kegiatan ini merupakan inisiatif masyarakat yang bekerjasama dengan peserta KPM dan juga karang taruna desa. Ini dilakukan di tempat masyarakat berlindung yang dekat dengan daerah KPM

c. Membersihkan masjid dan musholla sekitar

Kegiatan ini harus meminta izin kepada takmir masjid setempat setelah minta izin para pengurus sangat antusias pada kegiatan ini. Pengurus masjid sangat berterimakasih karena dengan adanya pengabdian masyarakat ini masjid selalu bersih dan banyak masyarakat atau para jamaah yang ada di masjid itu merasa nyaman dan tidak perlu khawatir lagi tentang kebersihan masjid tersebut. Disini kelompok KPM juga berpesan kepada masyarakat atau jamaah masjid tersebut agar tetap menjaga kebersihan masjid seterusnya meskipun KPM ini berakhir. Supaya hal ini dapat mencegah dan berusaha dalam merambatnya virus Corona yang mengalir deras bagaikan hujan tanpa awan.

Dalam kegiatan kuliah pengabdian masyarakat lainnya, diantaranya:

a. Membantu masyarakat, dalam kegiatan ini dilakukan dan menjalin silaturrahmi terhadap masyarakat dan juga mengedepankan saling bantu membantu sesama tetangga. Hal ini meliputi membantu membantu membangun rumah yang dimiliki masyarakat daerah sekitar KPM

b. Kegiatan membersihkan makam, dalam kegiatan ini dilakukan bersama sebagian warga setempat dan juga anak-anak bimbingan yang juga membantu dalam membersihkan makan tersebut. Hal ini bertujuan untuk 
mendapatkan pahala dan juga barokah serta untuk menjadikan teladan bagi peserta didik.

c. Membantu masyarakat, dalam kegiatan ini dilakukan dan menjalin silaturrahmi terhadap masyarakat dan juga mengedepankan saling bantu membantu sesama tetangga serta hal ini merupakan rasa empati peserta KPM kepada masyarakat sekitar. Hal ini meliputi membantu menanam tembakau yang dilakukan oleh bapak Nardi selaku tentannga peserta KPM.

d. Ikut serta berpartisipasi terhadap rapat sosialisasi COVID remaja arang taruna yang dilakukan di desa panagguan kecamatan larangan.

\section{Hasil dan Pembahasan}

Kegiatan kuliah pengabdian masyarakat di umah (KPM-DR) kepada masyarakat ini berjalan dengan sukses dan memberikan dampak positif bagi masyarakat di dusun Sumber dalam meningkatkan kesadaran dan pemahaman tentang COVID-19.

\section{a. Pencapaian}

Masyarakat mulai paham tentang apa itu COVID-19, bagaimana penyebaran COVID-19, dan bagaimana cara mencegahnya, terbukti dengan masyarakat yang mulai rajin cuci tangan setelah melaukan aktivitas yang berat maupun aktivitas yang ringan, dan juga masyarakat juga sudah mulai terbiasa menggunakan masker karena masyarakat tahu virus Corona tidak menyebar melalui udara. Namun, penggunaan masker dapat meminimalisir penularan virus Corona. sebab, virus Corona dapat menyebar melalui droplet dan dapat masuk ke dalam tubuh melalui selaput lender seperti mata, mulut, dan hidung. Dan juga masyarakat akhir akhir ini sudah rajin terhadap menjaga lingkungan sekitar rumah tinggalnya termasuk pada masjid-masjid yang dijadikan sembahyang masyarakat. Hal ini demi mencegah virus Corona menyebar dan ini merupakan sebuah usaha masyarakat.

Masyarakat juga mulai menerapkan hidup sehat dengan berolahraga setiap hari dan membersihkan sampah sampah yang berserakan karena mereka tahu sampah merupakan tempat yang disenangi oleh virus dan bakteri yang berbahaya.

\section{b. Tantangan}

Pertama, karena COVID-19 tergolong masih baru dan masih sedikit penelitian yang mengetahui tentang penyakit ini secara mendalam, banyak sekali berita yang tidak jelas kebenaran dan sumbernya. Contohnya, banyak beredar broadcast message berupa saran untuk mengonsumsi makanan tertentu untuk mendiagnosis COVID-19 di rumah. Mis informasi atau hoax seperti ini tentunya menimbulkan kebingungan. sebelum menyampaikan informasi kepada masyarakat, kita perlu memastikan sumber informasi yang dapat dipercaya. Cek kembali informasi yang kita dapatkan dengan sumber yang terpercaya dan pilah kembali mana berita yang bermanfaat dan terpercaya untuk disampaikan kepada masyarakat. 
Kedua, sebagian masyarakat menolak mengikuti saran pencegahan seperti social distancing. Mereka telah hidup lebih lama dan telah banyak makan asam garam kehidupan. Mereka mungkin telah melewati banyak kejadian sulit sepanjang hidupnya. Hal ini dapat menjadi alasan bagi sebagian masyarakat untuk sulit menerima informasi baru atau menganggap enteng wabah ini. Sebagian mungkin merasa sudah tua sehingga tidak masalah bila terkena dan meninggal, sebagian lainnya mungkin merasa masih sehat dan tidak akan terkena.

Ketiga, dinamika dalam keluarga. Terkadang, dinamika hubungan orangtua dengan anak dapat menghalangi seorang lansia menerima informasi. Peran sebagai orangtua ketika anak anaknya masih kecil menempatkan seseorang dalam posisi yang lebih mengetahui informasi dan bertanggung jawab terhadap anak anaknya. Terkadang, ketika anak telah dewasa dan orangtua menjadi lansiapun, sulit bagi orangtua untuk menerima bahwa kini mereka bertukar peran; anak anaknya yang menjaga dirinya. Bila kita merasa hal ini yang menyulitkan orangtua kita menerima informasi atau nasihat, coba sampaikan permintaan untuk mereka mengikuti saran pencegahan COVID-19 sebagai kebutuhan kita, bukan mereka. Misalnya: "Saya khawatir dengan wabah ini dan ingin mama sehat selalu, supaya terus bisa mendongeng untuk cucu cucu. karena itu, saya minta tolong ya Ma, sementara mama tidak usah bepergian dulu agar terhindar dari COVID-19."

Bila dinamika keluarga masih mengahalangi kita menyampaikan informasi, kita juga dapat mempertimbangkan untuk menyampaikan informasi melalui orang lain yang mungkin lebih didengarkan oleh mereka. ini tidak harus anggota keuarga lain atau orang seusia mereka.

Keempat, adanya gangguan kognitif atau fungsi pikir seperti demense, yang sering terjadi pada lansia. Hal ini tentunya mempengaruhi kamampuan seorang lansia menerima dan mengingat informasi. Akibatnya, lansia mungkin lupa melakukan tindakan pencegahan seperti mencuci tangan, Demense juga dapat menggangu proses komunikasi serta menyebabkan seseorang sulit memahami hubungan sebab akibat, sehingga harus meminimalisir bepergian selama wabah ini (Prasetya \& Sani, 2020).

\section{Kesimpulan}

Dari kegiatan KPM yang telah dilakukan dapat disimpulkan bahwa pencegahan dasar dalam menghadapi virus Corona ini sangat simple dan juga sederhana seperti memakai masker, mencuci tangan, menerapkan pisical distancing atau menjaga jarak, dan menjaga kebersihan lingkungan rumah dan sekitar.

Tetapi, kesadaran masyarakat terhadap kebersihan dan kesehatan lingkungan masih rendah. Hal ini menyebabkan rendahnya motivasi sebagian masyarakat untuk mengikuti kegiatan pengabdian ini. Namun setelah dilakukan pendekatan banyak masyarakat yang dengan penuh semangat mengikuti kegiatan ini sampai selesai. Rekomendasi ini saya tujukan kepada kepala desa beserta masyarakat untuk tetap meningkatkan 
kebersihan lingkungan dan menjaga kebersihan lingkungan. Semoga gerakan pencegahan COVID serta kesadaran ini tetap menjadi agenda masyarakat.

\section{Saran}

Berdasarkan temuan hasil kuliah pengabdian masyarakat (KPM) yang berjudul "Sosialisasi Covid-19 Dalam Rangka Pencegahan, Peningkatan Kesadaran Dan Pemahaman Masyarakat Tentang Covid-19 Di Desa Panaguan Kec. Larangan." Maka direkomendasikan sebagai berikut: 1) Pentingnya mencuci tangan dengan sabun pada setiap setelah melakukan aktivitas yang berlangsung. Ini dilakukan secara berkala. 2) Pentingnya menjaga jarak setidaknya 1 meter (3 kaki). Lebih-lebih pada tempat umum dan gerombolan orang-orang. 3) Perlunya untuk menghindari menyentuh mata, hidung dan mulut apabla sudah melakukan aktivitas. 4) Pentingnya mengikuti saran yang diberikan penyedia layanan atau pemerintah yang telah dianjurkan. 5) Pentingnya memakai masker pada setiap waktu. Seperti pada kerumunan orang banyak, bepergian, dan tempat umum. 5) Pentingnya menjaga lingkungan sehat, bersih dan juga damai. 6) Pentingnya menjaga imunitas tubuh supaya virus tidak masuk pada dalam tubuh.

\section{Daftar Pustaka}

Burhan, E. (2020). Pneumonia Covid-19 Diagnosis \& Penatalaksanaan di Indonesia. Jakarta: Perhimpunan Dokter Paru Indonesia.

European Centre for Disease Prevention and Control. (2020, September 7). Factsheet Health Profesional Coronavirus. Diambil 6 September 2020, dari European Centre for Disease Prevention and Control website: https://www.ecdc.europa.eu/en/factsheet-health-profesionalCoronaviruses

Hanum, F. (2006). Diklat Mata Kuliah: Sosioantropologi Pendidikan. Yogyakarta: Universitas Negeri Yogyakarta.

Hasan, N., \& dkk. (2018). Pedoman Penyelenggaraan Kuliah Pengabdian Kepada Masyarakat dengan Pendekatan Partisipatoris.

Kartono, K. (2007). Patologi Sosial (Jilid 1). Jakarta: PT. Raja Grafindo Persada.

Nur'aini, \& Wijaya, A. (2015). Singgah di Gerbang Kuliah. Semarang: Panembahan Senopati.

Parwanto, M. L. E. (2020). Virus Corona (2019-nCoV) penyebab COVID-19. Jurnal Biomedika dan Kesehatan, 3(1), 1-2. doi: 10.18051/JBiomedKes.2020.v3.1-2

Prasetya, V. G. H. P., \& Sani, T. P. S. (2020, September 6). Tantangan yang Mungkin terjadi Saat Menyampaikan Informasi terkait COVID-19 Kepada Lansia-Alzheimer Indonesia. Diambil 6 September 2020, dari https://alzi.or.id/tantangan-yang-mungkin-terjadi-saat-menyampaikaninformasi-terkait-COVID-19-kepada-lansia/ 
Wikipedia Bahasa Indonesia. (2020, September 6). Pengabdian Masyarakat. Diambil September 2020 , dari

https://id.m.wikipedia.org/wiki/Pengabdian_masyarakat 